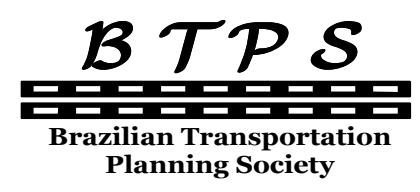

Planning Society

\author{
Journal of Transport Literature \\ Vol. 7, n. 2, pp. 268-283, Apr. 2013 \\ Research Directory
}

JTL | RELIT

www.transport-literature.org

\title{
Aviation war risk insurance and its impacts on US passenger aviation
}

[Seguro aeronáutico contra risco de guerra e impactos na aviação comercial Norte Americana]

\author{
Paul J. Freitas* \\ Technology Consult, United States
}

Submitted 8 Jun 2012; received in revised form 16 Jul 2012; accepted 4 Aug 2012

\begin{abstract}
In the aftermath of the September 11 attacks, the United States government became a supplier of aviation war risk (AWR) insurance for airliners, as well as a reinsurer for commercial insurance. Here we quantitatively examine the consequences of these offerings. The AWR offering is primarily needed for widebody and jumbo jets; smaller aircraft like the Embraer 195 are far less capable of creating damage in excess of the $\$ 50$ million AWR deductible. Widebody and jumbo jets are also the only aircraft capable of creating long-term government liability through its commercial reinsurance. The US government's assumed risk through its insurance involvement can reach into the hundreds of billions of dollars. This risk level can create a perceived financial incentive for government to force airline passengers through invasive and dangerous search procedures. Thus, governmental insurance offerings can create a conflict of interest that infringes air passengers' civil liberties.

Key words: aviation insurance; airlines; jets; wars.

Resumo

Após os ataques de 11 de setembro, o governo dos Estados Unidos tornou-se um fornecedor de seguro aeronáutico contra risco de guerra (AWR) para as companhias aéreas, bem como um ressegurador de seguros comerciais. Neste artigo foram examinadas, quantitativamente, as consequências deste fornecimento. 0 AWR é basicamente direcionado às aeronaves de grande porte (jatos widebody e jumbo); aeronaves menores, como o Embraer 195, são menos sujeitas à sofrerem danos que excedam os $\$ 50$ milhões de dólares dedutíveis pelo AWR. As aeronaves de grande porte são, também, as únicas capazes de criarem uma responsabilidade de longo prazo do governo através do seu resseguro comercial. 0 risco assumido pelo governo norte-americano tendo em vista o seu envolvimento com seguro pode alcançar os muitos bilhões de dólares. Este nível de risco pode criar um perceptível incentivo financeiro para que o governo force as companhias aéreas comerciais a tomarem medidas e procedimentos de segurança mais invasivos aos passageiros. Desta forma, o fornecimento do seguro governamental pode criar um conflito de interesses que infringe na liberdade civil dos usuários do transporte aéreo.
\end{abstract}

Palavras-Chave: seguro aeronáutico; companhias aéreas; jato; guerras.

*Email: paul@paulfreitas.com.

\section{Recommended Citation}

Freitas, P. J. (2013) Aviation war risk insurance and its impacts on US passenger aviation. Journal of Transport Literature, vol. 7, n. 2, pp. 268-283.

- JTL/RELIT is a fully electronic, peer-reviewed, open access, international journal focused on emerging transport markets and published by BPTS - Brazilian Transport Planning Society. Website www.transport-literature.org. ISSN 2238-1031.

This paper is downloadable at www.transport-literature.org/open-access. 


\section{Introduction}

It has been more than a decade since the September 11 attacks on the United States, in which four airliners captured by Al Qaeda suicide hijackers were used to attack targets on the ground. Approximately 3000 people were killed in total. The insurable damage from the event has been estimated to have cost \$35.9 billion in insured in 2006 dollars (Insurance Information Institute 2006). Only Hurricane Katrina has caused more insured damage from a single event.

These attacks clearly demonstrated the potential for devastation from large, fuel-laden airliners like the Boeing 767 crashing into highly-populated urban areas. One natural reaction to the September 11 attacks was to withdraw support for the use of large airliners. For example, private aviation insurers canceled their aviation war risk (AWR) insurance coverage shortly after the attacks, and when they later decided to offer coverage again, it had coverage limits below what was needed for large aircraft, as one can see below. Still, smaller aircraft like the regional jet and turboprop offerings of aircraft manufacturers like Brazil's Embraer and Canada's Bombardier can fit into these coverage limitations. It would have been natural for the bulk of passenger aircraft operations in the United States to have switched to smaller airframes.

This switch did not occur. Instead, the US government chose to address the uninsurability of large airliners by offering its own insurance. To address terrorism concerns, the United States also greatly increased its security requirements for airline passengers. Eventually the US Transportation Security Administration (TSA) started requiring a thorough physical search of every airline passenger, without regard for probable cause, starting in November of 2010. This screening requirement is frequently described as a violation of passengers' civil rights. TSA often conducts pat-down searches that include physical contact with passengers' breasts or genitals, and this part of the search is frequently compared to sexual molestation. TSA also uses body scanners that can create and transmit naked images of passengers. Some of these scanners have a small but measurable risk of producing lethal cancer in scanned subjects (Brenner 2011). Complaints of screener abuse of passengers are commonplace. 
In this paper we will examine how US government involvement in insurance markets allows airlines to use larger and riskier aircraft models like the Boeing 767, the airframe responsible for the bulk of the damages in the September 11 attacks, instead of switching to less risky airframes. We will review insurance changes in the United States in detail and demonstrate that US government insurance support benefits large airliners almost exclusively. These changes create financial incentives for the extreme security requirements now forced on US airline passengers, and slow the natural transition from risky airliners to safer ones.

Current literature includes a number of papers that describe how aviation and terrorism risk insurance have changed in the United States since the September 11 attacks. For aviation war risk insurance, Flouris et al. (2009) gives an excellent summary of how insurers priced risk in response to these attacks, and provides interesting total cost information. Also, Briones and Myers (2008) summarize the history and benefits to airlines of the US government aviation war risk insurance offering. Neither is critical of the government AWR program, however. Regarding commercial terrorism risk insurance, the Insurance Information Institute has several papers worth noting. One paper (Insurance Information Institute 2011) summarizes how the Terrorism Risk Insurance Act of 2002 and its extensions help provide terrorism risk insurance for commercial policies, spelling out clearly the obligations of government and private insurance. Another paper (Insurance Information Institute 2006) summarizes the damages of the September 11 attacks, which is at the time of this writing a unique event in the history of airline hijackings in terms of its destructiveness. None of these works examines the potential interaction between aviation war risk insurance and general commercial insurance, or how these policies can dramatically affect aviation security screening processes. This paper seeks to critically analyze government AWR and its potential effects in these other areas.

We will first examine aviation war risk insurance itself in the next section. In particular, we examine some potential claims for airliners of various sizes to see if government involvement in aviation war risk insurance is necessary in all cases. In the following section we examine the potential impact of aviation war risk insurance on other types of insurance, such as commercial insurance through the Terrorism Risk Insurance Act and its extensions. By offering insurance for airliners, the US government exposes itself to TRIA-related insurance losses that could amount to 
hundreds of billions of dollars. Next we examine the overall costs associated with both programs and propose a simple cost-benefit model that incorporates aviation security spending as well. Under this model, government expenses on aviation security can be assumed to be beneficial only if damages approximately equal to those of the September 11 attacks would otherwise be expected annually on average. The final section of the paper summarizes these conclusions in greater detail.

\section{Aviation war risk insurance}

War risk insurance, which includes coverage for terrorist incidents, is absolutely essential for modern airlines. Airliners cost tens of millions of US dollars or more, as we will see below, and insurance is a precondition for financing. Buyers unable or unwilling to obtain adequate insurance for airliners, including war risk insurance, will be unable to obtain financing for the purchase of an airliner. An owner of an existing aircraft faces loan default and aircraft repossession if it allows its aircraft insurance coverage to lapse. In particular, airlines need war risk coverage for aircraft, passengers, crew, and third-party liabilities similar to what they have for ordinary accidents. Before the September 11 attacks, private insurers offered war risk policies essentially for free. It was easily available along with all their other coverage like hull loss and general liability. This ease of availability changed after the September 11 attacks. Existing war risk policies were canceled one week later. Private insurers have refused to offer war risk policies for aviation at the same levels of coverage that they offered in 2001. In short, private insurance markets are no longer willing to provide the insurance airlines need for the fleets of aircraft they currently have and prefer to use.

Figure 1 shows the impact that the September 11 attacks had on overall airline insurance premiums. This data, collected by Flouris et al. (2009) clearly shows overall premiums spiking to almost quadruple what they were before the attacks. This yearly data hides some of the short term fluctuations immediately after the attacks. According to the US General Accounting Office (2003), the total annual cost of aviation war risk insurance for 14 major US carriers was $\$ 12$ million just prior to the September 11 attacks. Immediately afterwards, the price rose to $\$ 719$ 
million, an increase of almost 5892\%. In the long run, we can see in Figure 1 that insurance costs for airlines have dropped back into the range of values seen prior to the September 11 attacks.

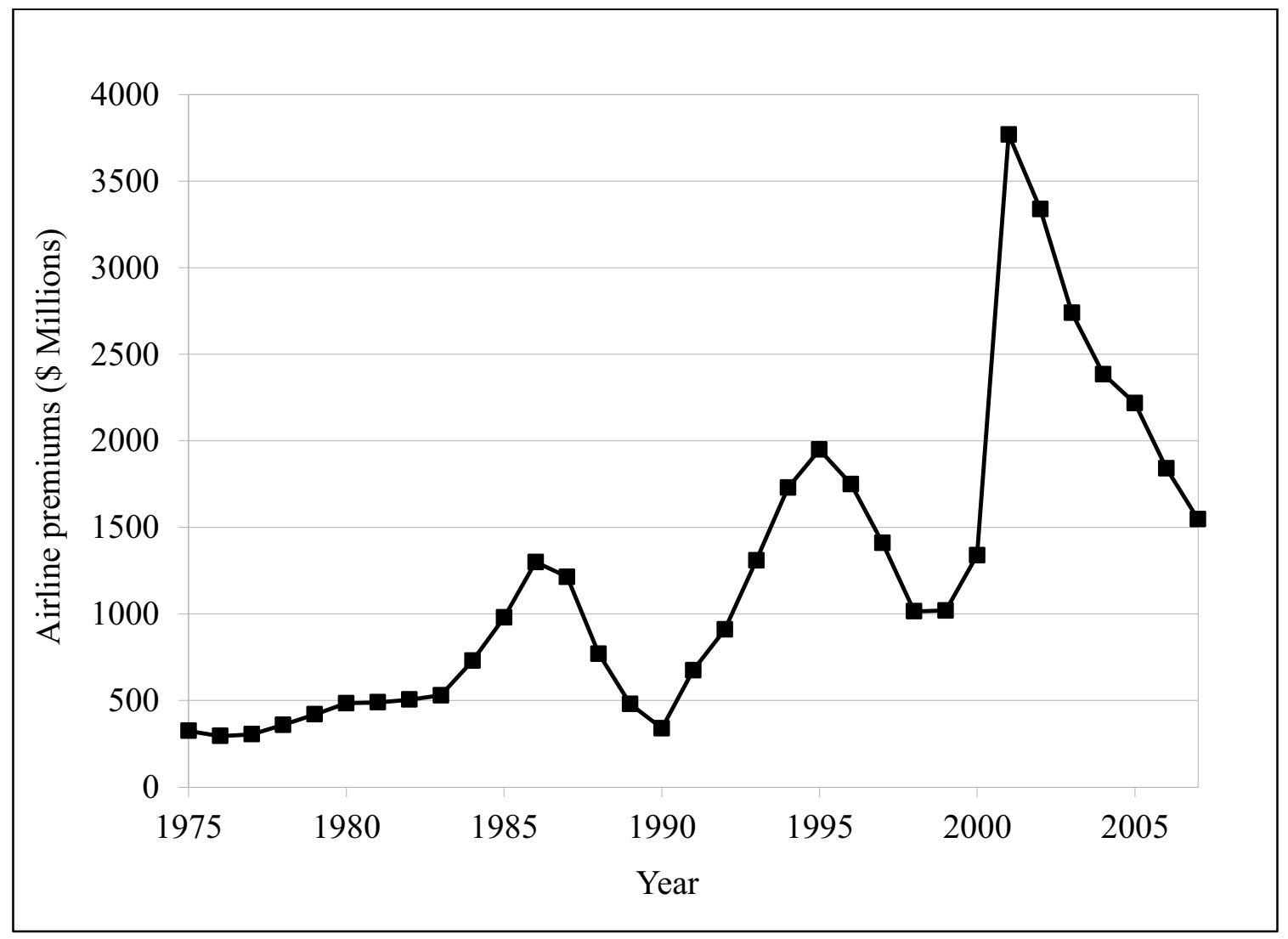

Figure 1 - Estimated airline premiums $(1995-2007)^{1}$

When insurance companies withdrew their airline war risk coverage, the United States government started offering the coverage through the Federal Aviation Administration. At present, the FAA offers Aviation War Risk (AWR) insurance against hull loss, passenger and crew loss, and third party liability with a deductible of no less than \$50 million (Federal Aviation Administration 2013, United States Code $)^{2}$. This government insurance deductible is covered by the aircraft owners' private insurance, and establishes a limit of what private insurance is willing

\footnotetext{
${ }^{1}$ Source: Flouris et al. (2009).

${ }^{2}$ Recent FAA budget proposals have attempted to raise the deductible to $\$ 150$ million, but these proposals have been unsuccessful thus far.
} 
to cover at the present time.

Table 1 - Aviation war risk liability estimates for specific aircraft

\begin{tabular}{|c|c|c|c|c|c|c|}
\hline Vehicle & $\begin{array}{r}\text { Typical } \\
\text { passenger } \\
\text { capacity }\end{array}$ & $\begin{array}{r}\text { Hull value } \\
\text { (millions) } \\
\text { (A) }\end{array}$ & $\begin{array}{r}\text { Low life } \\
\text { liability } \\
\text { (millions) } \\
\text { (B1) }\end{array}$ & $\begin{array}{r}\text { High life } \\
\text { liability } \\
\text { (millions) } \\
\text { (B2) }\end{array}$ & $\begin{array}{r}\text { Low } \\
\text { liability } \\
\text { (millions) } \\
(\mathrm{A}+\mathrm{B} 1)\end{array}$ & $\begin{array}{r}\text { High } \\
\text { liability } \\
\text { (millions) } \\
(\mathrm{A}+\mathrm{B} 2)\end{array}$ \\
\hline Bombardier CRJ700 & 75 & $\$ 37$ & $\$ 18.75$ & $\$ 150.00$ & $\$ 55.75$ & $\$ 187.00$ \\
\hline Bombardier Q400 & 78 & $\$ 32$ & $\$ 19.50$ & $\$ 156.00$ & $\$ 51.50$ & $\$ 188.00$ \\
\hline Boeing 717-200 & 106 & $\$ 37$ & $\$ 26.50$ & $\$ 212.00$ & $\$ 63.50$ & $\$ 249.00$ \\
\hline Embraer 195 & 122 & $\$ 40$ & $\$ 30.50$ & $\$ 244.00$ & $\$ 70.50$ & $\$ 284.00$ \\
\hline Boeing 737-700 & 149 & $\$ 71$ & $\$ 37.25$ & $\$ 298.00$ & $\$ 108.15$ & $\$ 368.90$ \\
\hline Airbus A320-200 & 150 & $\$ 88$ & $\$ 37.50$ & $\$ 300.00$ & $\$ 125.80$ & $\$ 388.30$ \\
\hline Boeing 767-200ER & 181 & $\$ 152$ & $\$ 45.25$ & $\$ 362.00$ & $\$ 196.75$ & $\$ 513.50$ \\
\hline Boeing 747-8 & 467 & $\$ 333$ & $\$ 116.75$ & $\$ 934.00$ & $\$ 449.65$ & $\$ 1,266.90$ \\
\hline Airbus A380-800 & 525 & $\$ 390$ & $\$ 131.25$ & $\$ 1,050.00$ & $\$ 521.15$ & $\$ 1,439.90$ \\
\hline
\end{tabular}

It is interesting to examine what this $\$ 50$ million of private coverage might actually cover in a terrorist incident. In Table 1 we calculate some plausible values for total damage for a number of passenger aircraft types currently in use in the United States. Damage estimates are in US dollars and include hull loss and passenger and crew loss of life, calculated using the rules discussed below.

For hull loss estimates, we will use aircraft manufacturers' listed prices for all aircraft except for the Bombardier Q400 and CRJ700, the out-of-production Boeing 717, and the Embraer 195. For these airframes, estimates were obtained from third-party sources. For passenger and crew loss of life, we will use estimates based on the September 11 Victims Compensation Fund (VCF) payouts. The VCF was a government-established fund used to compensate victims and their families for their losses on September 11. The minimum payout from the fund was $\$ 250,000$, and the average payout was approximately $\$ 2$ million (September 11th Victim Compensation Fund 2003). Here we will estimate economic damage using these values as low and high estimates, 
respectively, to try to come up with some reasonable estimates for economic damage to airlines and their insurers from loss of life.

The results in Table 1 are ordered from least economic impact to greatest. As one might guess, smaller capacity aircraft have the least potential economic liability, and larger aircraft have the greatest. The Bombardier CRJ700 and Q400 regional aircraft have a low liability estimate just $11.5 \%$ and 3\% (respectively) over the $\$ 50$ million deductible for the FAA war risk policy. Using the high estimate, these aircraft produce just under $\$ 190$ million in liability. While this is well beyond the current coverage limit for private insurance, that may not always be true. The Boeing 717-200, an out-of-production but still used variant of the venerable Douglas DC-9, and the Embraer 195 have estimates slightly higher than those of the CRJ700 due to its higher passenger capacity. To summarize, these smaller aircraft are close to being entirely privately insurable, at least in terms of hull loss and loss of life for passengers and crew, especially if loss of life liability could be legally limited to a figure like the $\$ 250,000$ per person given here. There are damage limitations on liability for lost baggage that may set a useful precedent for limiting loss of life liability.

Table 1 shows less encouraging results for the larger aircraft. If we use the low liability estimate and assume that private insurance coverage ultimately increases to $\$ 150$ million, we can realize private insurability for more aircraft like the Boeing 737-700 and the Airbus A320. This would cover most of the passenger aircraft in use in the US, but some notable aircraft would still be essentially uninsurable. The 767 would still require about a third more coverage than private insurance could offer. The 747 and A380 jumbo jets would be well outside the realm of private insurability, requiring over three times the coverage available privately. To allow these aircraft to operate, government must offer twice the coverage of private insurance at minimum. If one assumes the high limit tabulated above to be a better estimate, private insurance for these jumbo jets seems quite unrealistic, as private insurers must offer approximately 30 times the coverage they now offer. 


\section{The Terrorism Risk Insurance Act and its implications}

According to the Insurance Information Institute (Insurance Information Institute 2006), only about $13 \%$ of the insured damage of the September 11 attacks was paid by aviation insurers. The rest was covered by more common types of insurance such as life, property, and workers compensation insurance. In the event of another terrorist attack similar to the September 11 attacks, it is reasonable to assume that general insurance will once again be responsible for the majority of the damages.

Commercial property and casualty (sometimes called liability) insurance has been most notably affected by insurance market responses to the September 11 attacks. Like aviation war risk insurance, commercial property and casualty terrorism insurance became commercially unfeasible after the event. Insurers concluded that commercial properties in large cities were especially attractive targets for terrorism, and that these risks were much greater than they previously suspected. It was very likely that privately-offered insurance against terrorist acts would have vanished entirely for some period of time.

In response the US government passed the Terrorism Risk Insurance Act of 2002, or TRIA. The Insurance Information Institute has an interesting summary of this legislation (Insurance Information Institute 2011). This act and its extensions obligate the government to share in paying damages for terrorist acts for specified types of coverage, such as commercial insurance and business interruption insurance, where the insured has opted for TRIA coverage. Government assistance becomes possible once losses from a terrorist event across the insurance industry exceed \$100 million, and an individual insurer may apply for assistance once their losses exceed $20 \%$ of their annual commercial property and casualty premiums. The government will pay $85 \%$ of losses, leaving a $15 \%$ copayment to private insurance. The insurance industry as a whole is expected to pay at least $\$ 27.5$ billion per event, and the government may recoup funds from insurers if that amount is not met. Recoupment occurs through a maximum 3\% premium applied to all commercial property and casualty insurance policies until all expenditures have been recovered. This additional premium would apply to any policy of the specified type, even those that specifically exclude terrorism coverage. Total expenditures may now exceed $\$ 100$ billion 
dollars per event.

TRIA has many notable exclusions, such as coverage for weapons of mass destruction like chemical, biological, nuclear, or radiological weapons, making its coverage very limited. It would certainly be useful in an incident involving airline suicide hijackings, as it was designed to specifically cover that kind of occurrence. Truck bomb damage is also eligible for TRIA coverage. An American Academy of Actuaries estimate of the destructive capacities truck bomb attacks in various American cities, for example, placed the total damages from such an attack at a maximum of $\$ 11.8$ billion (American Academy of Actuaries 2006).

It is interesting to consider the amount of damage that might plausibly be done to a high-value target like New York City in another suicide hijacking attack, outside of that damage covered by aviation war risk insurance. By doing so, we can better evaluate the US government's potential liability exposure through TRIA. Here we will create a simple model for insurable damage, measured in billions of US dollars, for the aircraft listed in the previous section. We can then compare that amount with TRIA coverage limits as described above.

To create a model for damages, let us start with some actual damage figures from the September 11 attacks, which were estimated to have cost \$35.9 billion in insured damage in 2006 dollars (Insurance Information Institute 2006). If we now exclude the $\$ 4.6$ billion of September 11 damage that would have been covered by aviation insurance (aviation hull and liability), that leaves about $\$ 31.3$ billion covered by other insurance. In an earlier paper this author proposed that the total destructiveness of a given aircraft is proportional to the total amount of fuel it can carry (Author 2012). The insured damage from the September 11 attacks derived primarily from two Boeing $767 \mathrm{~s}$, each containing up to 63,000 liters of fuel. If we add up all the fuel from the $767 \mathrm{~s}$ alone and divide the non-aircraft insurable damage of September 11 by this total fuel volume, we can obtain an estimate of damage per unit fuel volume $d$ that is approximately $\$ 248,413$ per liter. To calculate damage potential for a given aircraft, defined here as $D$, we can use the simple formula $D=d V$, where $V$ is the total fuel volume (in liters) that an aircraft can carry. 
The value of $d$ selected here is for a dense urban area such as New York City. Potential damages in other parts of the country can vary widely, depending on additional factors like population density and property values. A similar attack against a different target, like San Francisco instead of New York City, would result in lower damages overall. The American Academy of Actuaries gave a quantified example of this phenomenon in considering various potential chemical, nuclear, biological, or radiological terrorist acts against four US cities: New York City, Washington D.C., San Francisco, and Des Moines (American Academy of Actuaries 2006). In all of the examples they presented, projected damages were at least $75 \%$ less for target cities outside of New York City. Similar reductions in damages from airline suicide hijackings are reasonable to expect.

Table 2 - General insurance liability estimates for specific aircraft ${ }^{3}$

\begin{tabular}{lrrr}
\hline Vehicle & $\begin{array}{r}\text { Typical } \\
\text { passenger } \\
\text { capacity }\end{array}$ & $\begin{array}{r}\text { Fuel capacity } \\
\text { (liters) }\end{array}$ & $\begin{array}{r}\text { Estimated } \\
\text { damage } \\
\text { potential } \\
\text { (billions) }\end{array}$ \\
\hline Bombardier CRJ700 & 75 & 11,028 & $\$ 2.74$ \\
Bombardier Q400 & 78 & 6,526 & $\$ 1.62$ \\
Boeing 717-200 & 106 & 13,903 & $\$ 3.45$ \\
Embraer 195 & 122 & 16,153 & $\$ 4.01$ \\
Boeing 737-700 & 149 & 26,020 & $\$ 6.46$ \\
Airbus A320-200 & 150 & 30,190 & $\$ 7.50$ \\
Boeing 767-200ER & 181 & 63,000 & $\$ 15.65$ \\
Boeing 747-8 & 467 & 229,980 & $\$ 57.13$ \\
Airbus A380-800 & 525 & 323,546 & $\$ 80.37$ \\
& & & \\
\hline
\end{tabular}

Table 2 shows some potential damage estimates, in billions of dollars, for another September 11 style attack calculated using the model described above. There are a number of interesting points to be made from these estimates. First, let us note their range. At the low end we have $\$ 1.62$ billion dollars for the Bombardier Q400, a regional turboprop aircraft. Its regional jet sibling, the CRJ700, is capable of much more damage ( $\$ 2.74$ billion). The $\$ 3.45$ billion estimate for the 717 200 is higher still, yet all three of these aircraft are capable of substantially lower damages than

\footnotetext{
${ }^{3}$ Source: author's own calculations.
} 
the benchmark $\$ 15.65$ billion a 767-200ER can do in a similar situation. The Boeing 737-700 could do less than half the 767-200ER amount of damage in similar circumstances. Because the Boeing 737 has had the highest sales of any jet passenger aircraft over all time, it seems reasonable to say that most passenger aircraft in use historically are simply not capable of doing the damage that we saw in the September 11 attacks.

Some aircraft, however, are capable of even greater destruction. The two jumbo jets in Table 2, the Boeing 747-8 and the Airbus A380-800, are capable of $\$ 57.13$ and $\$ 80.37$ billion in damages respectively. The A380 is the only passenger aircraft listed here that are capable of creating financial damage close to the $\$ 100$ billion limits once placed on TRIA reinsurance with only a single aircraft.

The smaller airliners tabulated above can essentially be covered by private insurance alone. Because of TRIA's recoupment provision, which allows the US government to recoup up to $\$ 27.5$ billion of its expenses from the commercial insurance industry overall, government will only have a long-term obligation for damages above that figure. Although damages from incidents involving aircraft like the Q400, CRJ700, 717-200, or even the 737-700 can amount to billions of dollars, these damage estimates are still well below the $\$ 27.5$ billion TRIA deductible. It would take a number of hijacked airliners acting in concert to meet the $\$ 27.5$ billion minimum. For example, it would take more than four coordinated 737-700 hijackings successfully hitting highvalue targets to match that damage figure. Terrorists seizing Q400s would require 17 aircraft to match that number.

\section{Overall costs to government from AWR and TRIA}

In the previous sections we looked at potential government liabilities for offering aviation war risk insurance and TRIA reinsurance. If we are to think of the US government as a kind of insurance company exposing itself to potential liability, we should also consider the revenues it receives in exchange. Any private insurance company hopes that over time the revenues it generates more than offsets the liabilities it incurs. If the US government could have a similar expectation, its actions could possibly be justified. It is worth taking a brief look at the US 
government's revenues from its insurance involvement and its related expenditures.

The US government charges nothing for TRIA reinsurance. The FAA's Airline War Risk insurance program, in contrast, does generate some revenue. The 2013 projected FAA budget forecasts $\$ 170$ million (or $\$ 0.17$ billion) in "collections from non-federal sources," or premium revenue from aircraft owners, for the year (Federal Aviation Administration). The US government spends approximately $\$ 5.1$ billion annually on aviation security through the Transportation Security Administration (Department of Homeland Security). In addition to the AWR revenue mentioned previously, the US government imposes the Aviation Passenger Security Fee (APSF) on airline passengers to offset some of the aviation security cost. This fee is projected for 2013 to raise only about $\$ 2.2$ billion from airline passengers, leaving about $\$ 2.7$ billion in costs not offset by revenue from AWR or APSF. It is interesting to consider a possible financial motivation for such an expenditure.

We can view the US government's heavy expenditure on aviation security, and extensive passenger screening in particular, in terms of activities insurance companies use to minimize their future liabilities. For example, many health insurance plans offer "wellness programs" that pay benefits for plan members to quit smoking or lose weight, in hopes that these measures will improve the members' overall health and reduce future insurance company liabilities. One can view aviation security measures in a similar light. The United States federal government has become a kind of insurance company, and the money it spends now on airport security, though great, should prevent activities that would force them to pay even greater claims later through AWR and TRIA.

It follows that by spending approximately $\$ 2.7$ billion per year on aviation security, unoffset by fees or other dedicated revenue, the US government demonstrates a belief that it would otherwise be liable for more than this amount annually. For this to occur, let us assume that the government's primary form of liability is through TRIA reinsurance and that government recoups all possible expenses from private insurance. For it to be left with $\$ 2.7$ billion in liability a terrorist incident causing $\$ 30.2$ billion or more in insured damage must occur. This amount is comparable to the amount of insured damage sustained in the September 11 attacks. So, from a 
purely financial perspective, it makes sense for the US government to overspend by $\$ 2.7$ billion annually on aviation security if it believes that, by doing so, it is preventing an attack of September 11 magnitude or more each year. It is reasonable to question the credibility of such a threat assessment.

Even if there was a credible reason to believe that an attack at least as damaging as the September 11 attacks might happen every year, TSA's screening methods are unlikely to prevent such attacks. These screening methods, which include full body scanners and aggressive pat-downs, have often been criticized as being ineffective and easily circumvented. There have been many reports of passengers inadvertently and unknowingly bringing weapons (including loaded firearms) through TSA screening and onto aircraft. Millimeter-wave body scanners have a high false-positive rate, approximately 50\%, and are widely known to be fooled by passenger sweat, zippers, and clothing pleats. Kaufman and Carlson pointed out that X-ray body scanners could not detect certain objects hidden on a person's side (Kaufman and Carlson 2011), a vulnerability that was apparently verified by Corbett (Corbett 2012).

The social cost of aggressive passenger screening is very high. Both full body scanners and patdowns can have extreme negative consequences. Body scanning frequently involves displaying naked images of passengers to screeners, which raises privacy concerns at minimum. Pat-down searches at present include breast and genital areas, which makes them physically identical to acts of sexual molestation. These pat-downs cause psychological and emotional distress for many passengers and, in the case of minors, their parents or guardians, who fear for their safety and wish to protect them from becoming victims of a sex crime. X-ray body scanners can also cause potentially lethal cancers through radiation poisoning. One researcher has estimated that X-ray body scanners likely cause hundreds of cancer deaths per year (Brenner 2011).

Still, if attacks of September 11 magnitude are at all possible, perhaps that is because aircraft of the size used in the September 11 attacks are still heavily used. In fact, the largest aircraft in US skies today are larger than those present in 2001, presenting greater risks in the event of a suicide hijacking attack. Reducing the size of passenger aircraft is a better way to protect against such large disasters. 


\section{Conclusions}

We have seen above that US government offered AWR insurance has enabled US airlines to continue to use and purchase large airliners similar to, and in some cases more dangerous than, those used in the September 11 attacks. Smaller aircraft are much less in need of the government offering, because they are much less likely to cause damage in excess of the $\$ 50$ million already covered by private insurance, especially if damages are limited by law. By enabling the continued use of these aircraft, the US government inadvertently exposes itself to hundreds of billions of dollars of risk through TRIA and its extensions. Because AWR and TRIA are not financially selfsufficient, these government insurance supports create financial incentives for invasive passenger screening regimes. If one believes terrorist attacks equivalent to those of September 11, 2001 are likely to occur on average every year, the current level of aviation security spending can be considered obligatory, to protect the financial interests of US taxpayers.

Although ending the FAA's AWR program could leave many aircraft uninsurable, this is not necessarily an undesirable outcome. The Terrorism Risk Insurance Act of 2002 and its extensions have specific exclusions for radiological, chemical, biological, and nuclear attacks. Airline suicide hijacking may be the largest threat remaining that could create TRIA liability for the government. Of the airframes that could potentially be used in a suicide hijacking, only widebody and jumbo jets are capable of creating enough damage in a dense urban area like New York City where the US government might have long term TRIA liability.

The US government may perceive financial incentives for spending $\$ 2.7$ billion, unoffset by dedicated revenue, on aviation security if by doing so it expects to thwart suicide hijacking attacks whose damage would total at least $\$ 30.2$ billion or more annually on average, roughly equivalent in value to the insured damage of the September 11 attacks. Whether such attacks are reasonable to expect is highly questionable, as is the assertion that aviation passenger screening changes since 2010 could actually prevent such attacks.

The US government can best protect itself financially by allowing free markets to select out the greatest threats, large airliners, through insurability. Even if it is politically difficult for the US 
government to ban these aircraft directly (many of these aircraft are manufactured domestically), it is likely unwise to ignore the greater wisdom of free markets and deny them the opportunity to make the decision instead. By not interfering in terrorism insurance markets, the US might realize improved safety against terrorism greater than aviation security changes are capable of achieving. The greatest threats and most tempting terrorist targets, exceptionally large airliners, could disappear from American skies without any need for direct government intervention.

The US government can also end its conflict of interest between its Constitutional duty to advance the civil liberties of its citizens and its fiduciary responsibilities to taxpayers to protect itself from financial liability. The US government forcing invasive screening on airline passengers has created routine civil liberties violations including warrantless searches, detainments, radiation poisoning exposures, and various forms of sexual misconduct, just to name a few. These actions may make sense to the US government as a method for mitigating financial liability if one believes that they actually work as intended, but are contrary to the Bill of Rights in the US Constitution and the interests of individual citizens. If the US government can exit its involvement in aviation war risk insurance markets, the conflict of interest can end.

\section{References}

Airbus (2012) New Airbus aircraft list prices for 2012. Available at www.airbus.com.

American Academy of Actuaries (2006). Response to president's working group on financial markets: terrorism risk insurance analysis. Available at www.actuary.org.

Boeing (2012) Boeing commercial products web site. Available at www.boeing.com.

Brenner, D. J. (2011) Are x-ray backscatter scanners safe for airport passenger screening? For most individuals, probably yes, but a billion scans per year raises long-term public health concerns. Radiology, vol. 259, pp. 6-10. Available at radiology.rsna.org.

Briones, C. and Myers, H. (2008) Shortchanged: how airlines can repay taxpayers for billions in subsidies by improving jobs, security and services. East Bay Alliance for a Sustainable Economy, pp. 9-11. Available at www.workingeastbay.org.

Corbett, J. (2012) \$1B of TSA nude body scanners made worthless by blog - how anyone can get anything past the scanners. Available at tsaoutofourpants.wordpress.com.

Department of Homeland Security (2012) FY 2013 budget-in-brief, United States Department of Homeland Security. Available at www.dhs.gov.

Federal Aviation Administration (2012) Budget estimates fiscal year 2013. Available at www.dot.gov. 
Freitas, P. J. (2012) Passenger aviation security, risk management, and simple physics. Journal of Transportation Security, vol. 5, n. 2.

Flouris, T., Hayes, P., Pukthuanthong-Le , K. and Walker, T. (2009) Recent developments in the aviation insurance industry. Risk Management and Insurance Review, vol. 12, n. 2, pp. 227-249.

Insurance Information Institute (2011) Terrorism risk and insurance. Available at www.iii.org.

Insurance Information Institute (2006) $9 / 11$ and insurance: the five year anniversary. Available at www.iii.org.

Kaufman, L. and Carlson, J. W. (2011) An evaluation of airport x-ray backscatter units based on image characteristics. Journal of Transportation Security, vol. 4, pp. 73-94.

September 11th Victim Compensation Fund (2003) Award payment statistics. Available at www.justice.gov.

United States of America (2012) United States Code $\$ 44302(g)(2)$. Available at www.gpo.gov.

United States General Accounting Office (2003). Aviation assistance: information on payments made under the disaster relief and insurance reimbursement programs. GAO-03-1156R, p. 33. Available at www.gao.gov. 